\title{
BIOCHEMICAL AND HISTOPATHOLOGICAL CHANGES INDUCED BY SODIUM MONOFLUOROACETATE (1080) IN MALLARD DUCKS
}

\author{
J.M. ATARIA ${ }^{1}$, M. WICKSTROM ${ }^{2}$, D. ARTHUR ${ }^{3}$ and C.T. EASON ${ }^{1,4}$ \\ ${ }^{1}$ CENTOX Centre for Environmental Toxicology, Landcare Research, \\ PO Box 69, Lincoln \\ ${ }^{2}$ University of Saskatchewan, 44 Campus Drive, Saskatoon, SK S7N 5B3, Canada \\ ${ }^{3}$ Labworks Laboratory, PO Box 113, Lincoln University, Lincoln \\ ${ }^{4}$ Author for correspondence
}

\begin{abstract}
Public concern over inadvertent kills of native birds following large-scale aerial poisoning operations for possum has highlighted deficiencies in information concerning the effects of 1080 on nontarget species. In this study biochemical and histopathological changes were measured in adult male mallard ducks (Anas platyrynchos) dosed orally with 1080 . The toxin was quickly absorbed into the blood and distributed to the cardiac tissue. The time taken to reach maximum 1080 concentrations in these tissues corresponded closely with the onset of clinical signs of toxicosis. Tissue and serum citrate accumulation is a direct result of 1080-induced inhibition of the Krebs Cycle enzyme aconitate hydratase. Histopathological lesions indicated that skeletal muscle was a target organ for 1080-induced damage in birds. Dosedependent increases in serum creatinine kinase (CK) and aspartate aminotransferase (AST) were consistent with extensive muscle necrosis. Skeletal muscle may be a unique avian-specific target organ for 1080 . Keywords: Sodium monofluoroacetate, ducks, toxic effects.
\end{abstract}

\section{INTRODUCTION}

Sodium monofluoroacetate (1080) has been widely used to control vertebrate pests in New Zealand. The non-target effects of 1080 have been studied extensively during the last 20 years (Spurr 1991, 1994; Spurr and Powlesland 1997; Powlesland et al. 1999). There have been frequent reports of dead birds being found after aerial application of 1080 baits. Most dead birds were found after large-scale control operations and trials using undyed, raspberry-lured, unscreened carrot bait that had a high percentage of small fragments or 'chaff'. Reductions in bird deaths can be attributed to the screening of carrot baits to remove small fragments, the banning of raspberry lure, the use of cinnamon oil as a partial deterrent, the reduced rates of bait application and the increased use of cereal-based baits.

Extensive monitoring indicates that populations of common forest birds are not adversely affected (Spurr 1994). However, some endangered bird species (e.g. kiwi and kokako) have been less frequently monitored, at least for some bait types. In contrast to the finding of Spurr (1994), Powlesland et al. (1999) showed that there can be significant mortality of robins (43-55\%) immediately after aerial 1080 operations. However, they agreed that these are short-term effects which are offset by long-term benefits to robin populations, through an increased breeding success and decline in possum and rat populations. Occasional reports of inadvertent kills of native birds following aerial poisoning operations have highlighted deficiencies in our understanding of the effects of 1080 on non-target species at an individual and population level.

While there is a very extensive database in the acute toxicity of 1080 to birds, there is little information available regarding the short- and long-term detrimental effects that may result from sub-lethal exposure. The aim of this research was to determine 
the target organs and sub-lethal effects of 1080 in a common bird species to a dose of 1080 that could be encountered in the environment after a 1080 poison operation, and would be likely to kill some ducks but would be a sub-lethal dose to other individuals.

\section{METHODS}

Adult male mallard ducks (Anas platyrynchos) were dosed orally with 1080 (Tull Chemical Co. Oxford, Alabama, USA) at 0 (control) or $8 \mathrm{mg} / \mathrm{kg}$. The $\mathrm{LD}_{50}$ for ducks is thought to be approximately $9 \mathrm{mg} / \mathrm{kg}$ (Rammell and Fleming 1978; Eisler 1995), which suggests that an adult duck would have to eat between three and six baits (approximately $4 \mathrm{~g}$ containing $0.15 \%$ 1080). Individuals were sacrificed at $0,2,4,6$, 12 or $24 \mathrm{~h}$ after dosing. Elevated serum citrate levels due to 1080 poisoning were measured using enzymatic bio-analysis kit (Boehringer Mannheim) based upon the technique of Möllering and Gruber (1966). Concentrations of 1080 were determined in serum and heart tissue according to the method of Ozawa and Tsukioka (1987) as follows. Sodium monofluroacetate was isolated from serum and aqueous tissue preparations on an ion exchange column, then derivatised with N,N'dicyclohexylcarbodiimide and 2,4-dichloroaniline, and quantified by gas chromatography on a BP-5 capillary column with electron capture detection. Selected serum biochemistry analyses were performed by MAF Laboratories using an automated whole blood analyser (Hitachi 704 Analyser, Boehringer Mannheim, Germany). Tissues for histopathological examination were fixed in $10 \%$ formalin. Tissue blocks were then sectioned to $5 \mathrm{~mm}$, stained with haematoxylin and eosin, and examined using light microscopy. Biochemical data were analysed for significant differences between treatment groups and the corresponding control group using either Fisher's LSD test or Bonferroni's test. Animal Ethics approval for these studies was obtained from the Landcare Research Animal Ethics Committee.

\section{RESULTS}

The profiles of 1080 concentration as a function of time were very similar in serum and heart tissue, although serum concentrations were almost double those measured in heart tissue for the first $6 \mathrm{~h}$ (Fig. 1). Maximum concentrations occurred about $2 \mathrm{~h}$ after dosing then decreased rapidly. Concentrations of 1080 increased rapidly in the serum and heart tissue. Maximum concentrations of $12.95 \mathrm{mg} / \mathrm{ml}$ and $8.01 \mathrm{mg} / \mathrm{g}$ were measured in the serum and heart, respectively, at $2 \mathrm{~h}$ after dosing, before decreasing

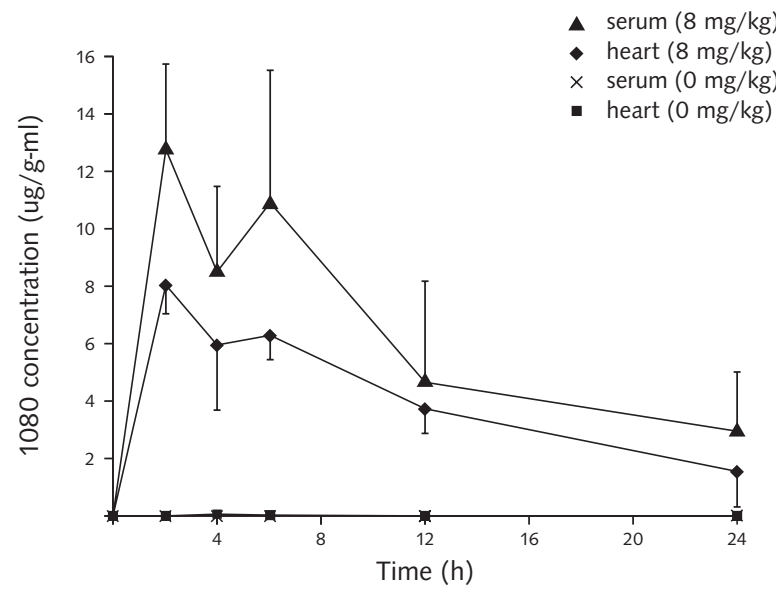

FIGURE 1: Mean concentrations ( $n=4$ for each point) of $1080( \pm 95 \% \mathrm{CI})$ in serum and heart tissue in the high-dose group $(8 \mathrm{mg} / \mathrm{kg})$ compared to controls. Treatments were significantly different from controls $(\mathbf{P}<0.001)$ at all time points. 


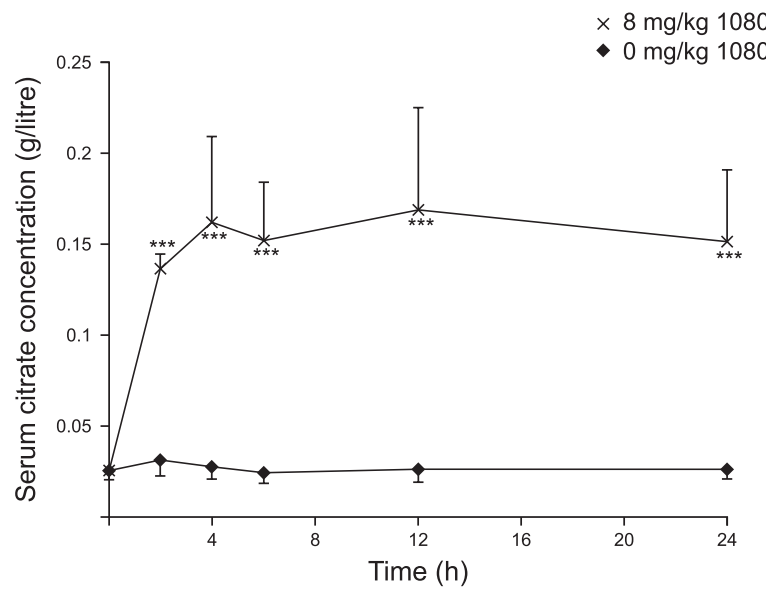

FIGURE 2: Mean serum citrate concentrations $( \pm 95 \% \mathrm{CI})$ after a single oral dose of 1080 compared to controls. Significant differences between treatments and controls are shown $(* * * \mathbf{P}<0.001)$.

rapidly over time. At $24 \mathrm{~h}$ after dosing 1080 was still detectable in both tissues. Serum citrate concentrations increased quickly to reach maximum levels $4-12 \mathrm{~h}$ after dosing with 1080 (Fig. 2). Serum citrate concentrations remained elevated at $24 \mathrm{~h}$.

Histological examination of selected tissues revealed lesions in the skeletal muscle characterised by severe focal necrosis and fragmentation of myofibres (Fig. 3). Muscle lesions were only observed in birds that died within $2 \mathrm{~h}$ of exposure, but epicardial haemorrhages were observed $24 \mathrm{~h}$ after dosing in all surviving birds dosed

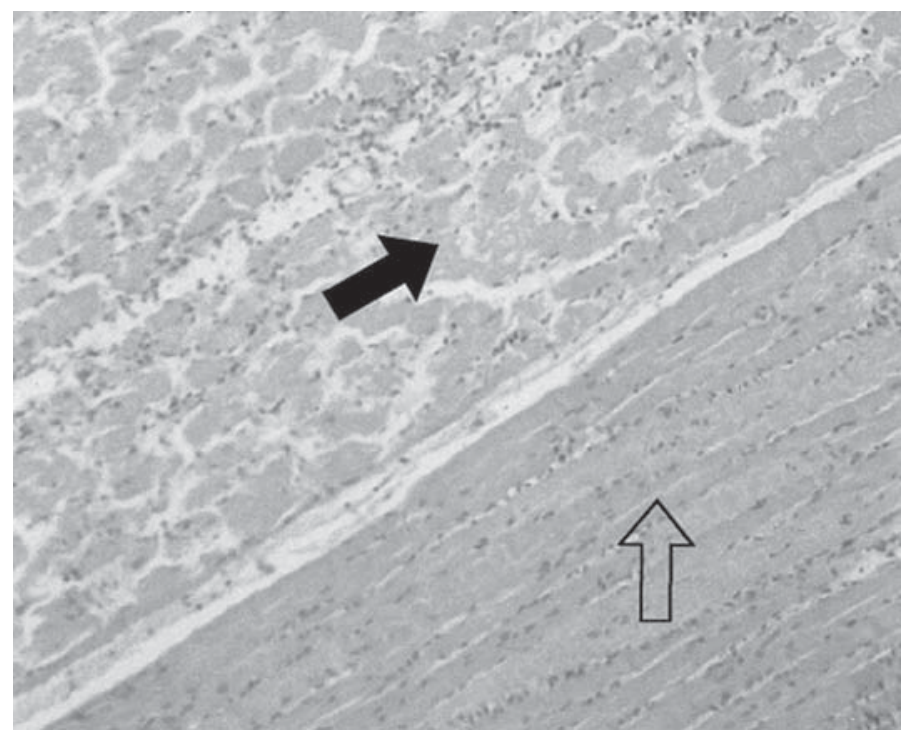

FIGURE 3: Skeletal muscle from birds that died after dosing with 1080 at $8 \mathrm{mg} /$ $\mathrm{kg}$. Areas of focal necrosis and myofibre fragmentation (closed arrows) are shown adjacent to normal muscle tissue (open arrows). 


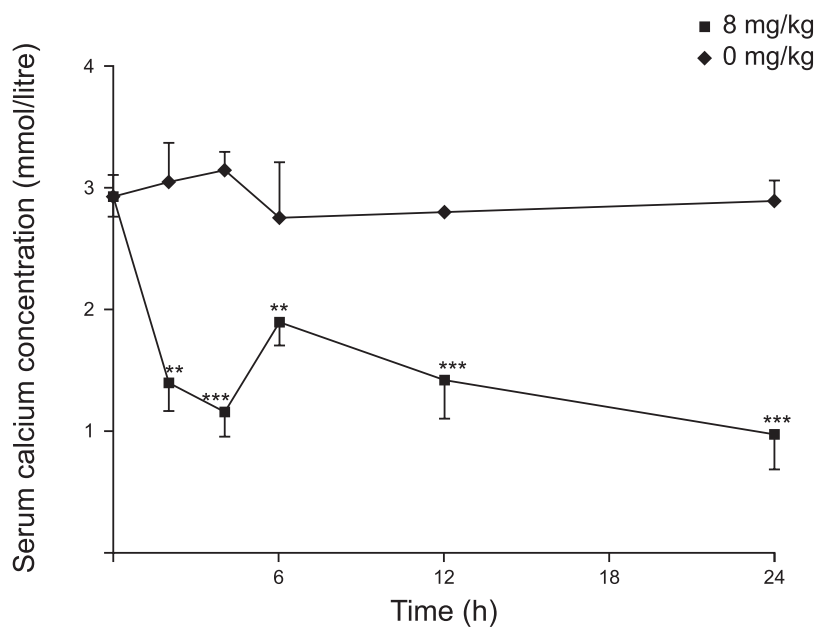

FIGURE 4: Mean total serum calcium concentrations $( \pm 95 \%$ CI $)$. Significant differences between treatments and controls are shown $(* * P<0.01$, *** $\mathbf{P}<\mathbf{0 . 0 0 1 )}$.

with 1080. A transient increase in serum AST activity above controls was observed after $6 \mathrm{~h}$ in birds dosed with 1080 (data not shown). Similarly, serum CK increased slowly to peak at $6 \mathrm{~h}$ before returning to normal (data not shown).

Serum uric acid concentration increased to a maximum at $6 \mathrm{~h}$ in birds dosed at 8 $\mathrm{mg} / \mathrm{kg}$, then decreased over time. It remained significantly greater than controls $(\mathrm{P}<0.05)$ at $24 \mathrm{~h}$ (data not shown). Conversely, serum calcium concentrations decreased significantly in the treated group to reach a minimum at $4 \mathrm{~h}$, and remained significantly depressed $(\mathrm{P}<0.001)$ at $24 \mathrm{~h}$ (Fig. 4).

\section{DISCUSSION}

Sodium monofluoroacetate is rapidly absorbed and distributed to the heart, skeletal muscle, and other tissues in ducks following oral administration. The time taken to reach maximum toxin concentrations in these tissues corresponded closely with the onset of clinical signs of toxicosis in this study. Our experiment demonstrates that 1080 does not persist in ducks and concentrations in heart muscle and blood had been substantially eliminated $24 \mathrm{~h}$ after dosing. Similar results have been obtained in other mammalian species (Eason et al. 1994). Tissue and serum citrate accumulation results from 1080-induced inhibition of the Krebs Cycle enzyme aconitate hydratase. Elevated serum citrate concentrations in turn may act to chelate calcium ions (Hornfeldt and Larson 1990), accounting for the decrease in total serum calcium observed in the 1080-treated dose group. Histopathological lesions indicated that skeletal muscle is a target for 1080-induced damage. The high energy requirements of avian muscle tissue may make it susceptible to 1080-induced disruption of cellular energy metabolism in a way not reported for mammals exposed to the toxin. Dosedependent increases in serum CK and AST are consistent with muscle necrosis. However, the transient increases in these enzymes suggest that muscle damage was localised. Increases in serum uric acid may be due to kidney damage, but in the absence of renal lesions, are more likely to be secondary due to dehydration. Substantial biochemical and histopathological changes would be expected at near-lethal doses. However, in a separate study significant elevation in citrate levels has been observed at doses as low as $2 \mathrm{mg} / \mathrm{kg}$ (J. Ataria, unpubl. data).

Based on these experimental findings we conclude that the pharmacokinetics and toxicokinetics of 1080 poisoning in birds is similar to mammals (Eason et al. 1999). 
Even at a sub-lethal dose of 1080 equivalent to the consumption of less than half of a single 1080 bait pellet, changes in biochemical biomarkers were measured. How these poison-induced changes may affect the long-term health of ducks has not yet been evaluated. The tissue damage observed at high doses suggests that skeletal muscle may be a unique, avian-specific target organ for 1080. It is recommended that histopathological examination of the skeletal muscle of poisoned birds be used as an indicator of 1080 poisoning.

The comparatively few published studies that exist on the sub-lethal effects of 1080 (Eason et al. 1999; O'Connor et al. 1999) indicate that histopathological damage to key target organs may occur at extremely low dose levels. There is some species variation in the target organs that are affected by 1080 which may, in part, be due to differences in biochemical responses of different organs or, in the case of birds, reflect heightened metabolic activity in muscle tissue. Exposure to sub-lethal doses may in some instances be sufficient to have long-term detrimental effects. The effects observed in this study in key organs, such as heart and wing muscle, highlights the need to monitor individuals or populations in the medium- to long-term to ensure there are no longer-term adverse effects on non-target wildlife. Effort to minimise exposure of birds continues to be of paramount concern to wildlife management agencies. Histopathological examination of wing muscle could assist in the diagnosis of 1080 poisoning.

\section{ACKNOWLEDGEMENTS}

We thank Eric Spurr and Kathryn O'Halloran for reviewing this manuscript; Lynne Milne and Andrea Rhodes for assisting with the conduct of the study; Geoff Wright for undertaking 1080 analyses. This research was supported by the New Zealand Foundation for Research, Science and Technology.

\section{REFERENCES}

Eason, C.T., Gooneratne, R. and Rammell, C.G., 1994. A review of the toxicokinetics and toxicodynamics of sodium monofluoroacetate in animals. Pp 124-133 In: A.A. Seawright and C.T. Eason (Eds); Proceedings of the Science Workshop on 1080. Roy. Soc. N.Z. Misc. Series 28.

Eason, C.T., Wickstrom, M., Turck, P. and Wright, G.R.G., 1999. A review of recent regulatory and environmental toxicology studies on 1080: results and implications. N.Z. J. Ecol. 23: 129-137.

Eisler, R., 1995. Sodium monofluoroacetate (1080) hazards to fish, wildlife, and invertebrates: synoptic review. U.S. Dept of the Interior Nat. Biol. Serv. Biol. Report 27. 47 p.

Hornfeldt, C.S. and Larson, A.A., 1990. Seizures induced by fluoroacetic acid and fluorocitric acid may involve chelation of divalent cations in the spinal cord. Eur. J. Pharmacol. 179: 307-313.

Möllering, H. and Gruber, W., 1966. Determination of citrate with citrate lyase.Anal. Biochem. 17: 369-376.

O’Connor, C.E., Milne, L.M., Arthur, D.G., Ruscoe, W.A. and Wickstrom, M., 1999. Toxicity effects of 1080 on pregnant ewes. Proc. N.Z. Soc. Anim. Prod. 59: 250253.

Ozawa, H. and Tsukioka, T., 1987. Gas chromatographic determination of sodium monofluoroacetate in water by derivatization with dicyclohexylcarbodiimide. Anal. Chem. 59: 2914-2917.

Powlesland, R.G., Knegtmans, J.W. and Marshall, I.S.J., 1999. Costs and benefits of aerial 1080 possum control operations using carrot baits to North Island robins (Petroica australis longipes), Pureora Forest Park. N.Z. J. Ecol. 23: 149-159.

Rammell, C.G. and Fleming, P.A., 1978. Compound 1080: properties and use of sodium monofluoroacetate in New Zealand. Ministry of Agriculture and Fisheries, Wellington. $137 \mathrm{p}$.

Spurr, E.B., 1991. Effects of brushtail possum operations on non-target bird populations. Proc. 20th Internat. Ornithol. Congress: 2534-2545. 
Spurr, E.B., 1994. Review of the impacts on non-target species of sodium monofluoroacetate (1080) in baits used for brushtail possum control in New Zealand. Pp 124-133 In: A.A. Seawright and C.T. Eason (Eds); Proceedings of the science workshop on 1080. Roy. Soc. N.Z. Misc. Series 28.

Spurr, E.B. and Powlesland, R.G., 1997. Impact of aerial application of 1080 on nontarget fauna. Science for Conservation 62: 31. Department of Conservation, Wellington, New Zealand. 